\title{
Folate and folic acid in the periconceptional period: recommendations from official health organizations in thirty-six countries worldwide and $\mathrm{WHO}$
}

\author{
Sandra Gomes ${ }^{1,2}$, Carla Lopes ${ }^{1,2}$ and Elisabete Pinto ${ }^{2,3, *}$ \\ ${ }^{1}$ Institute of Public Health of the University of Porto (ISPUP), Porto, Portugal: ${ }^{2}$ Department of Clinical Epidemiology, \\ Predictive Medicine and Public Health, University of Porto Medical School (FMUP), Porto, Portugal: ${ }^{3} \mathrm{CBQF}$ (Centro \\ de Biotecnologia e Química Fina) Laboratório Associado, Escola Superior de Biotecnologia, Universidade Católica \\ Portuguesa/Porto, Rua Arquiteto Lobão Vital, Apartado 2511, 4202-401 Porto, Portugal
}

Submitted 27 June 2014: Final revision received 29 December 2014: Accepted 21 January 2015: First published online 16 April 2015

\begin{abstract}
Objective: To summarize the recommendations on folate intake and folic acid supplementation and fortification in the periconceptional period, aimed at prevention of neural tube defects (NTD), provided by official health organizations in different countries worldwide and WHO.

Design: Information on recommendations for folate and folic acid intake in the periconceptional period was gathered from the websites of official national health organizations of several countries worldwide and from the WHO website.

Setting: WHO, selected developed countries and emerging economies, totalling thirty-six countries worldwide (some European, BRICS, G8, Asian Tiger/Asian Dragon and Australia).

Results: Recommendations differ between countries, although the majority (69.4\%) recommend a healthy diet plus a folic acid supplement of $400 \mu \mathrm{g} / \mathrm{d}$ from preconception (4-12 weeks) until the end of the first trimester of pregnancy (8-12 weeks). The same recommendation is issued by the WHO. Dosages for women at high risk of NTD are up to $4-5 \mathrm{mg} / \mathrm{d}$ (for $41.7 \%$ of studied countries). The recommended intake for folate is in the range of 300-400 $\mu \mathrm{g} / \mathrm{d}$ for women of childbearing age and 500-600 $\mu \mathrm{g} / \mathrm{d}$ for pregnant women in different countries and WHO. Five countries emphasize the importance of a healthy diet rendering supplementation needless. By contrast, five others advise a healthy diet and supplementation plus mandatory fortification. Only one mentions the importance of ensuring an adequate folate status and refers to checking with a health-care provider on the need for supplements.

Conclusions: Different recommendations regarding folate and folic acid, seeking NTD prevention, are available worldwide; however, most countries and WHO focus on a healthy diet and folic acid supplementation of $400 \mu \mathrm{g} / \mathrm{d}$ periconceptionally.
\end{abstract}

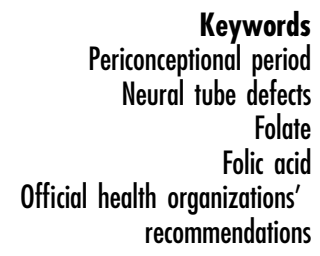

Keywords Perconceptional period defects

olic acid recommendations
Worldwide, more than $10 \%$ of infant deaths secondary to congenital anomalies are caused by nervous system anomalies $^{(1)}$. Neural tube defects (NTD) are the most common major congenital anomalies of the central nervous system, constituting an important public health problem in terms of mortality, morbidity, social cost and human suffering ${ }^{(2)}$. The incidence of NTD ranges from $0 \cdot 5$ to 14 per 1000 live births ${ }^{(3)}$.

The findings obtained from randomized trials by the British Medical Research Council in $1991^{(4)}$ and by the Hungarian National Institute of Hygiene (a WHO Collaborating Centre for the Community Control of Hereditary
Diseases) in $1992^{(5)}$ about the effect of periconceptional folic acid supplementation on NTD prevention were revolutionary and remain consensual to the present day ${ }^{(6)}$. Furthermore, folic acid seems to prevent other congenital anomalies (cleft lip ${ }^{(7,8)}$ and cardiovascular malformations), but the results are not consistent ${ }^{(2,5,9,10)}$. The relationships between maternal folate levels and other pregnancy outcomes, such as placental abruption, placental weight and gestational age, also remain inconclusive $e^{(11-14)}$.

Curiously, in two observational studies, folic acid supplementation did not show any influence on trends of incidence of NTD ${ }^{(15,16)}$, probably because most women 
started supplementation after the target period ${ }^{(17)}$. In order to prevent NTD, and considering that the neural tube closes by day $28^{(18)}$ when most women do not know they are pregnant ${ }^{(2)}$, even in planned pregnancies, folic acid supplementation should start before conception ${ }^{(6,19)}$. However, estimates indicate that $41 \%$ pregnancies worldwide are unintended ${ }^{(20)}$.

Regarding these promising results provided by the randomized trials, the water-soluble nature of folic acid and the unawareness of adverse effects (apart from neurological complications in people with vitamin $\mathrm{B}_{12}$ deficiency ${ }^{(6)}$ ), combined with the difficulty of global supplementation in the desired period, fortification of foods with this vitamin has been considered safe ${ }^{(21)}$. This motivated some countries to opt for folic acid fortification of cereal products, namely flour. Nowadays, fortification of flour with folic acid is mandatory in forty-seven countries, in the continents of America and Oceania, in the Middle East and a few in Africa ${ }^{(22,23)}$. The effectiveness of mandatory folic acid fortification has been studied in some countries and a significant decline in prevalence of some NTD was observed; for instance, after mandatory folic acid fortification in the USA and Canada, the occurrence of some NTD declined by $28 \%{ }^{(24)}$ and $46 \%{ }^{(25)}$, respectively. Nevertheless, part of this decline can be explained by better prenatal screening and the termination of affected pregnancies ${ }^{(26)}$. Moreover, in a recent review, the authors defended that women of childbearing age may not yet be adequately targeted, while the general population may be over-fortified with folic acid ${ }^{(27)}$. Uncertainties remain over the minimum effective folate intake and status required for NTD prevention, and the safe upper folate level ${ }^{(27)}$. Voluntary fortification is permitted in most European countries, but none has mandatory fortification ${ }^{(15)}$. Recently the EU introduced new rules to regulate voluntary food fortification ${ }^{(15)}$.

After mandatory folic acid fortification, many questions arose regarding individual liberty (to choose fortified or nonfortified foods) and about feasible monitoring of potential hazards of the fortification ${ }^{(15)}$. The possible carcinogenicity of excessive intake of folic acid has been suggested ${ }^{(2,28)}$, supported by biologically plausible mechanisms: folate is essential in biological methylation reactions and nucleotide synthesis and impairment of these processes is thought to be involved in cancer development ${ }^{(15)}$. Some researchers suggested that a link could exist between high folic acid intake and cancer incidence ${ }^{(29,30)}$, but this is not consensual ${ }^{(15,31,32)}$.

Recently, a new concern has arisen regarding the potential adverse effects of universal maternal supplementation on adverse pregnancy outcomes, early or later in life, both in the mother and child ${ }^{(13,33)}$. Studies have associated maternal folic acid supplementation with increased birth weight ${ }^{(11-14)}$, insulin resistance in children $^{(34)}$ and asthma in children ${ }^{(35,36)}$.

Overall, current evidence suggests that the relationship between maternal folic acid supplementation and pregnancy outcomes displays a U-shaped association, with adverse effects at both low and high dosages. Official health institutions should deliver clear and evidence-based messages regarding folic acid intake in order to maximize health gains and to minimize adverse effects.

The present study aimed to summarize the recommendations on folate intake and folic acid supplementation and fortification, in the periconceptional period, aimed at NTD risk reduction, provided by official health organizations in different countries worldwide and WHO. This work could constitute a first step of a global discussion about the divergences between recommendations, in order to improve them.

\section{Methods}

Data about folate (provided by diet) and folic acid (provided by supplements or fortified foods) recommendations in the periconceptional period were obtained from national health official websites across forty-six countries worldwide and from the WHO website. Eligibility criteria for country selection, defined by the research team, were the following: EU countries (Austria, Belgium, Bulgaria, Croatia, Cyprus, Czech Republic, Denmark, Estonia, Finland, France, Germany, Greece, Hungary, Ireland, Italy, Latvia, Lithuania, Luxembourg, Malta, Netherlands, Poland, Portugal, Romania, Slovakia, Slovenia, Spain, Sweden and UK) and some European countries not belonging to the EU (Iceland, Liechtenstein, Norway, Switzerland and Turkey) that were mentioned on the European Commission website, on the web page entitled Public Health - Trustworthy websites on 'Population groups $^{\text {(37); }}$ BRICS countries (Brazil, Russia, India, China and South Africa); Group of Eight (G8) countries (that include some EU and BRICS countries already stated; they are Canada, France, Germany, Italy, Japan, Russia, UK and USA); Asian Tiger/Asian Dragon countries (Hong Kong, Singapore, South Korea and Taiwan); and Australia.

Developed countries and emerging economies (according to the UN, International Monetary Fund, Organisation for Economic Co-operation and Development, and World Bank) in well-defined groups were selected because of the easiest access to data.

The keywords used for searching in each country's websites were the following: folic acid, folate, pregnancy and nutrition. These terms and the information found in the countries' websites were translated on Google ${ }^{\circledR}$ Translate, from English to the official languages and vice versa. Ministry of Health websites were chosen for their national coverage of the recommendations. However, for some countries we considered scientific organizations' websites when mentioned or linked with the Ministry of Health website.

Data extracted from each website covered the following topics: (i) amount of recommended folate intake for 
women of childbearing age and pregnant women (measured in folate or dietary folate equivalents (DFE)); (ii) recommendation of a healthy diet and folate-rich foods; and (iii) folic acid supplementation for NTD risk reduction (recommended dosage, tolerable upper intake level (UL), dosage for high risk of NTD, when to start and to finish the supplementation). Data about mandatory folic acid fortification were obtained at the European Surveillance of Congenital Anomalies (EUROCAT) website ${ }^{(23)}$. The names of the official entities, the types of information (for health professionals or the general public) and the website addresses were also registered for further validation. Only nine countries (25.0\%) had all desired information available (Australia, Austria, Denmark, Estonia, Finland, Germany, Switzerland, Canada and USA).

Websites were chosen instead of collecting data from scientific articles or sending emails to each national health representative asking for information, because the found reviews $^{(16,38)}$ did not include all the desired countries nor all information. We also intended to find which information is available through the World Wide Web, where many people (from health professionals to the general public) consult and follow health recommendations ${ }^{(39-41)}$. Information on mandatory fortification was collected only to complete this overview, since we intended to summarize information that could be searched by people and used to influence their behaviours. Mandatory fortification is a governmental decision that potentially affects the whole population.

Emails were sent for all forty-six selected countries in order to obtain data validation or to obtain missing data (data that could be on the website, but had not yet been found). In the validation process, the information was confirmed, corrected and/or completed. Data without official validation were equally considered for results and analysis, after confirmation from the websites on at least three different days.

Data were collected from May until October 2013, and updated in December 2014.

\section{Results}

From the forty-six countries initially considered, ten $(21.7 \%)$ were excluded - six in the EU (Croatia, Cyprus, Czech Republic, Greek, Lithuania and Slovakia), two European countries not belonging to the EU (Liechtenstein and Turkey), one BRICS country (India) and one Asian Tiger/Asian Dragon country (South Korea) - on the basis of data being unavailable or not found. Thus a final sample of thirty-six countries was obtained: twenty-two in the EU (Austria, Belgium, Bulgaria, Denmark, Estonia, Finland, France, Germany, Hungary, Ireland, Italy, Latvia, Luxembourg, Malta, Netherlands, Poland, Portugal, Romania, Slovenia, Spain, Sweden and UK), three European countries not belonging to the EU (Iceland, Norway and Switzerland), four BRICS countries (Brazil, Russia, China and South Africa), three more G8 countries (the other five were already stated in EU and BRICS; Canada, Japan and USA), three Asian Tiger/Asian Dragon countries (Hong Kong, Singapore and Taiwan) and Australia; see Fig. 1.

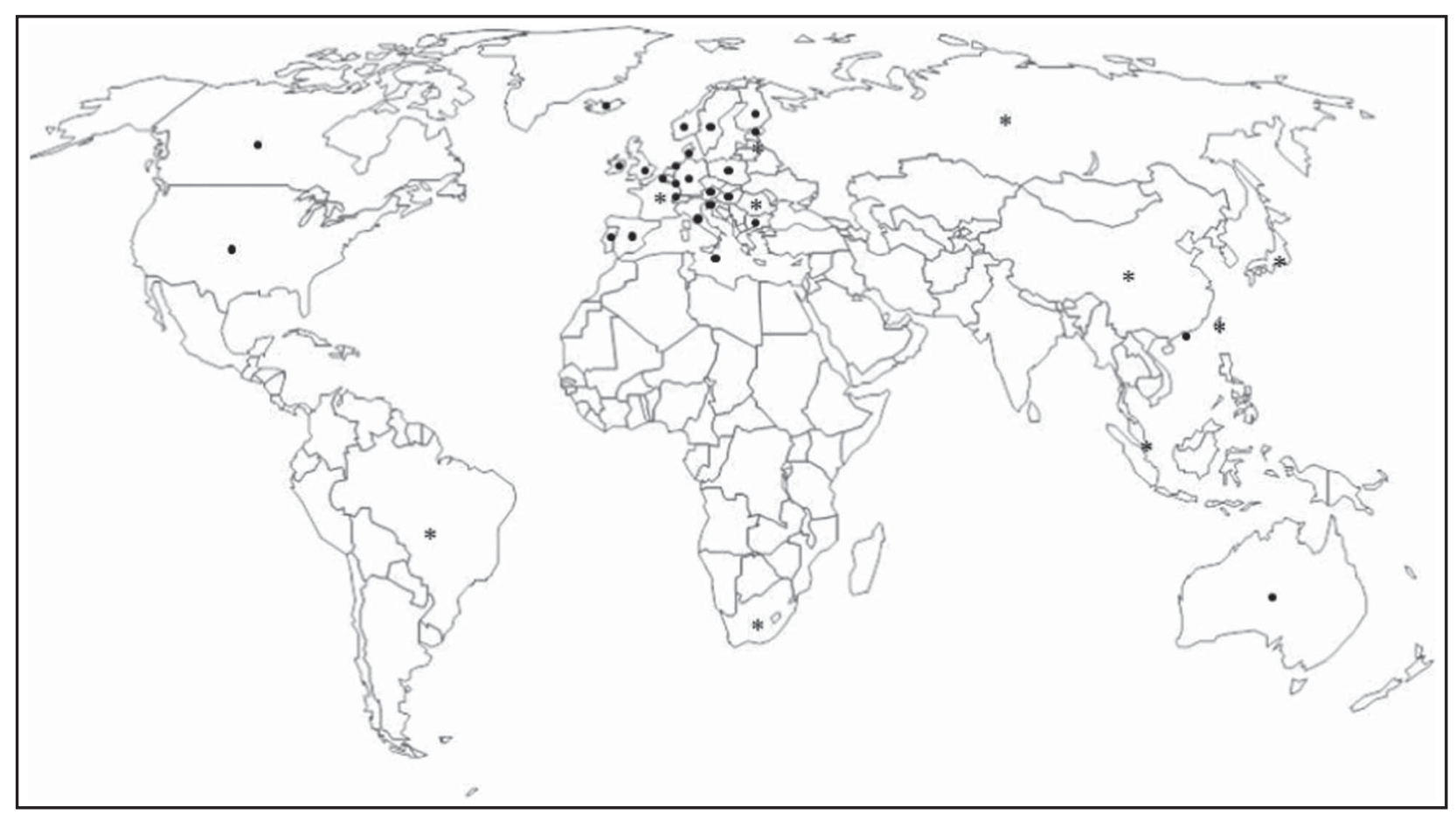

Fig. 1 World map showing the thirty-six countries in which recommendations for folate and folic acid intake in the periconceptional period were analysed $(0$, country with official validation; $*$, country without official validation) 
From the thirty-six countries included, twenty-six countries validated the information by email (72.2\%) and ten did not (Brazil, China, France, Japan, Latvia, Romania, Russia, Singapore, South Africa and Taiwan). From the other ten countries without data, only Liechtenstein validated the (missing) information. The WHO did not validate data.

The recommendations for folate and folic acid intake in the periconceptional period are synthesized in Table 1.

A healthy diet and/or folate-rich food recommendations were issued by all countries (100.0\%), but the WHO website only mentioned it for women with high risk of NTD. Interestingly, five countries (13.9\%; Finland, France, Sweden, Singapore and Taiwan) considered that a healthy diet containing adequate amounts of folate may be enough, with no need for supplementation. Three countries (Hong Kong, Slovenia and Sweden) published e-leaflets for the general public with complete and detailed information about healthy diet during pregnancy, consumption of folate-rich foods, cooking methods and quantities. Eight more countries (Austria, Denmark, Estonia, France, Iceland, Luxembourg, Taiwan and Poland) also published e-leaflets with information for pregnant women including healthy diet. Some others mentioned it directly on the website.

Concerning recommended folate intake (and estimated average requirements) for women of childbearing age and pregnant women, respectively, we identified three main different recommendations: (i) Dietary Reference Intakes from the US Institute of Medicine (IOM; followed by $22.2 \%$ of countries), namely $400 \mu \mathrm{g} / \mathrm{d}$ and $600 \mu \mathrm{g} / \mathrm{d}$ $(320 \mu \mathrm{g} / \mathrm{d}$ and $520 \mu \mathrm{g} / \mathrm{d})$; (ii) Nordic Nutrition Recommendations from the Nordic Council of Ministers (NNR; followed by $16.7 \%$ of countries), namely $400 \mu \mathrm{g} / \mathrm{d}$ and $500 \mu \mathrm{g} / \mathrm{d}(200 \mu \mathrm{g} / \mathrm{d})$; and (iii) reference values for the nutrient intake from the dominant states of the German language (Deutschland-Austria-Confoederatio Helvetica (D-A-CH); followed by $8.3 \%$ of countries), namely $300 \mu \mathrm{g} / \mathrm{d}$ and $550 \mu \mathrm{g} / \mathrm{d}(220 \mu \mathrm{g} / \mathrm{d}$ and $420 \mu \mathrm{g} / \mathrm{d})$. WHO adopted the folate recommendations from the $\operatorname{IOM}^{(28,42)}$. About half of the countries $(52.8 \%$ ) did not have any references regarding recommended folate intake through diet. For Switzerland, different values were available in the two sources consulted (D-A-CH and those referred by the Swiss Federal Office of Public Health). Slovenia followed D-A-CH recommendations, with high values only after the first trimester. This appears more practicable as physiologically women have higher energetic needs in the second and third trimesters ${ }^{(43)}$, notwithstanding the role of folate after the first trimester is not completely established. It is also apparent that NNR presented the smallest increase from preconception to pregnancy, possibly more attainable. The highest values from the IOM seem less achievable than those from D-A-CH or NNR.

Regarding folic acid supplementation for NTD prevention, the majority ( $n 33,91.7 \%$ ) of the analysed countries have some information on their national health official websites about this topic. Most countries (80.6\%) recommend a folic acid supplement of $400 \mu \mathrm{g} / \mathrm{d}$, two countries state that the dosage should be recommended by a healthcare provider (without mentioning any dosage) and one country recommends $5 \mathrm{mg} / \mathrm{d}$. Concerning the time for initiating the supplementation, $33.3 \%$ of countries state at least 4 weeks before conception, as settled by D-A-CH recommendations; $27 \cdot 8 \%$ of countries state that 'supplementation should begin when planning pregnancy' or 'when there is a chance to become pregnant/capable of becoming pregnant', as stressed by the IOM recommendations; $13.9 \%$ of countries mention at least 12 weeks before pregnancy; two countries refer to 4-8 weeks or 8-12 weeks before conception; two advocate to start when contraception is stopped; and one country recommends at least 8 weeks before stopping contraception. Most countries (75.0\%) consider that supplementation should be maintained until the end of the first trimester (12 weeks) or almost (10 or 8-12 weeks), but three countries (Canada, China and USA) recommend supplementation until the end of pregnancy.

On the subject of the UL, $44.4 \%$ of countries and two entities (D-A-CH and IOM) state $1 \mathrm{mg} / \mathrm{d}$ and two countries appeal for not exceeding the recommendations without mentioning the UL. Finally, the dosages recommended for women with high risk of NTD are $5 \mathrm{mg} / \mathrm{d}$ (adopted by $27.8 \%$ of countries and by WHO recommendations) or $4 \mathrm{mg} / \mathrm{d}$ (considered by $13.9 \%$ of countries). Some countries suggest these dosages should be discussed with a physician ( $8.3 \%$ of countries and D-A-CH recommendations) and two countries refer to only 'higher dosages'.

Although the observed recommendations differ between countries, the recommendation for folic acid of $400 \mu \mathrm{g} / \mathrm{d}$ before conception until the first trimester of pregnancy is common for most countries (69.4\%) and WHO.

Countries partially out of this common recommendation are those that recommended $5 \mathrm{mg} / \mathrm{d}$ (Brazil) or supplementation throughout pregnancy (Canada, China and USA) or that did not show the dosage, referring to check with a health-care provider on the need for taking supplements and to ensure an adequate folate status (Singapore). This resembles an attempt to personalize the intervention.

Some countries had incomplete information about supplementation as follows: dosage was missing in Portugal; time for initiation was absent in Romania; the end time was missing in South Africa, Portugal and Romania; and supplementation was not mentioned at all in Russia, Slovenia and Taiwan.

Taiwan's website referred that the best method to ensure sufficient folate for fetal development is to consume foods high in folate on a frequent basis, giving examples. This perspective contrasted with that of countries with a focus mainly on supplementation, for example Netherlands and USA. 


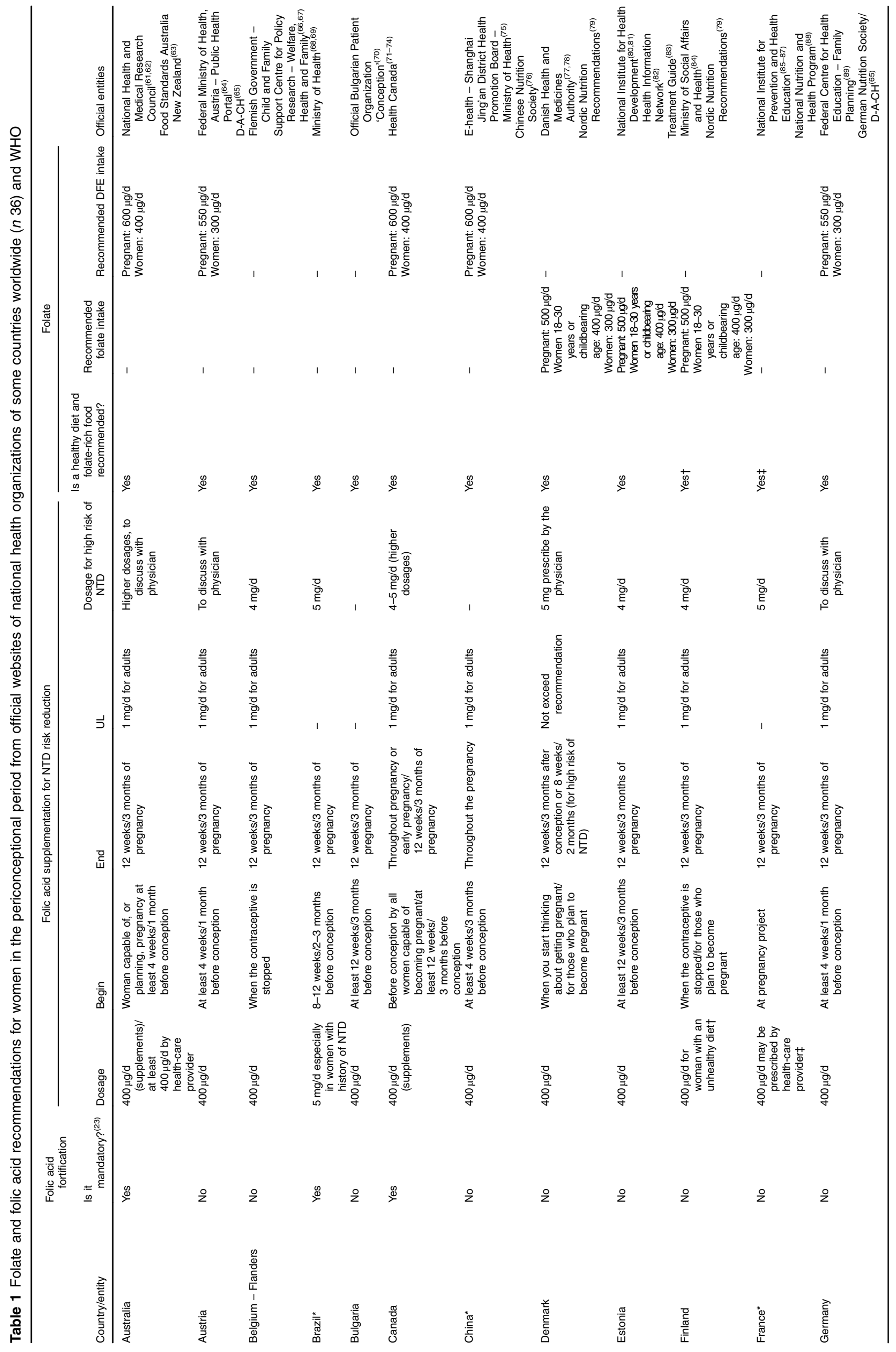




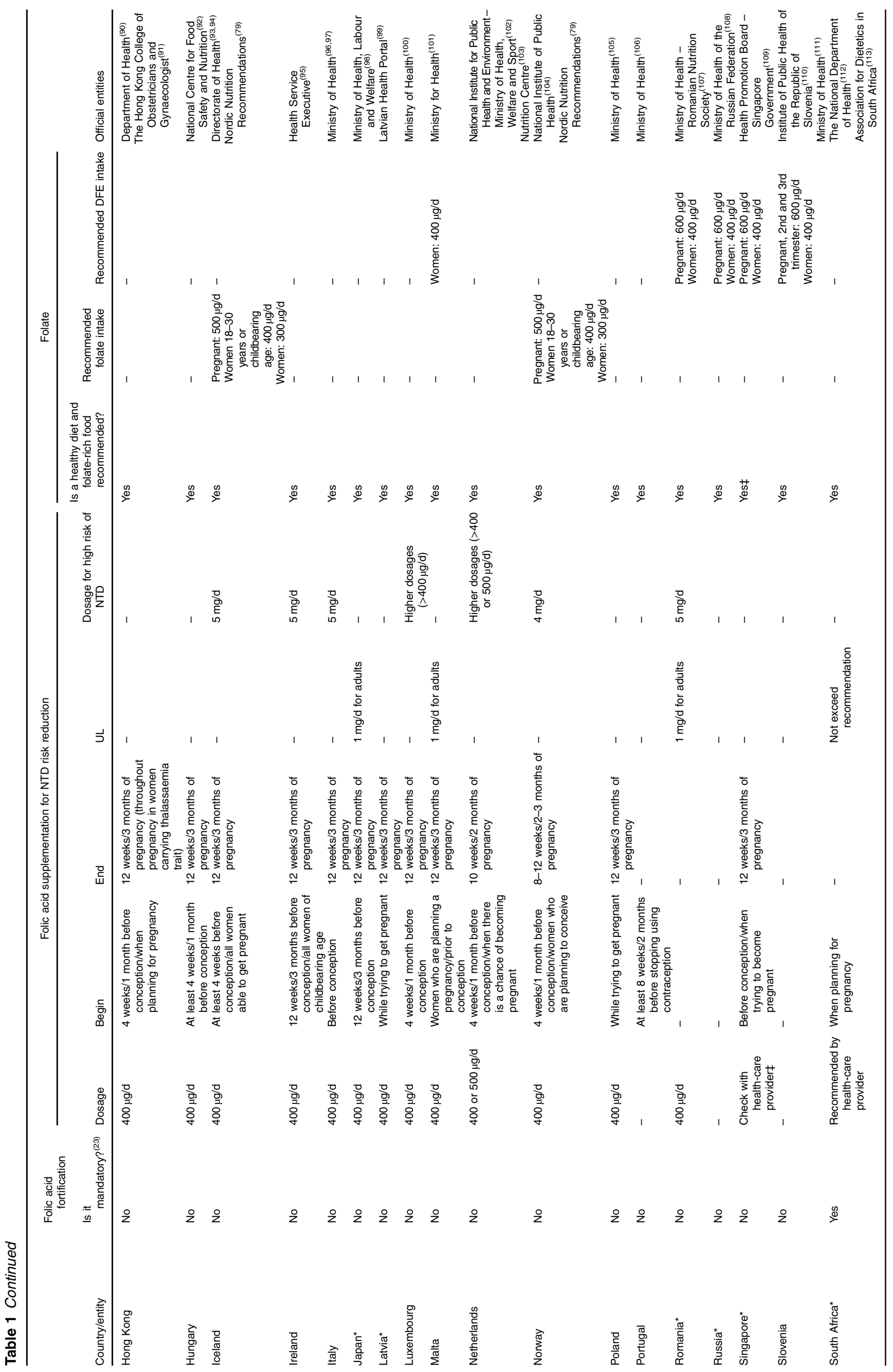




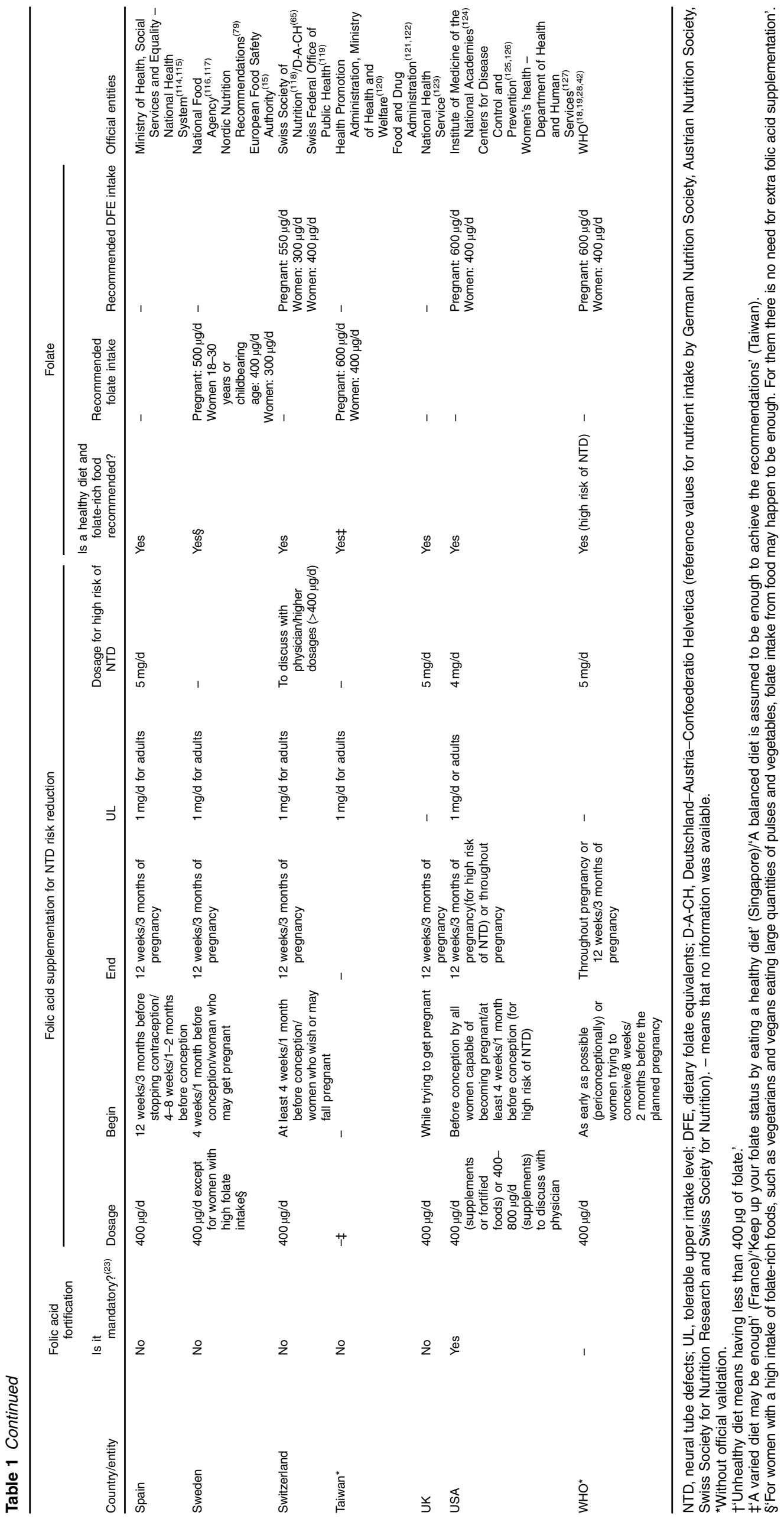




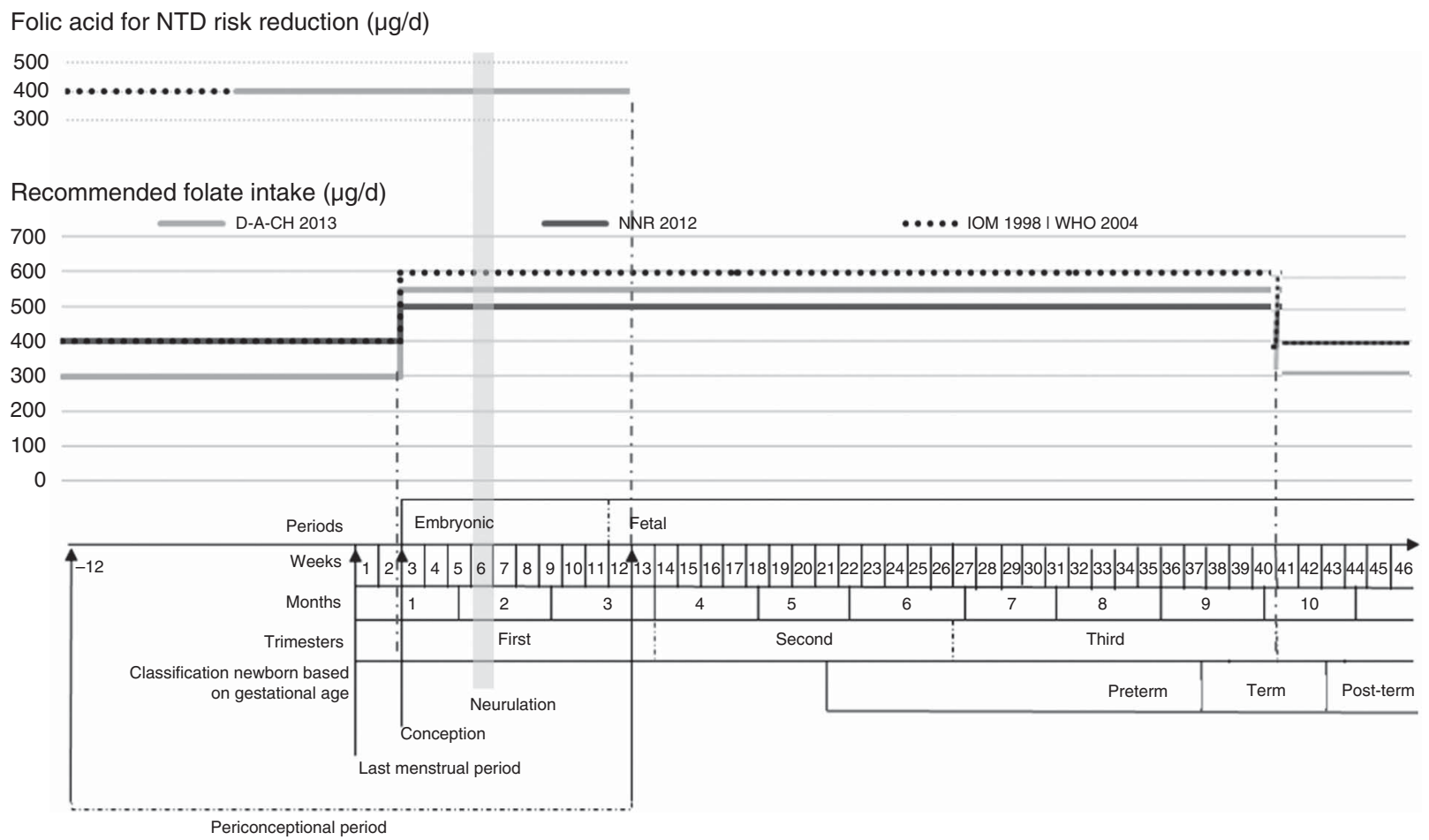

Fig. 2 Recommended folate intake and recommended folic acid supplementation for prevention of NTD during the periconceptional period (NTD, neural tube defects; D-A-CH, Deutschland-Austria-Confoederatio Helvetica (reference values for nutrient intake by the German Nutrition Society, Austrian Nutrition Society, Swiss Society for Nutrition Research and Swiss Society for Nutrition); NNR, Nordic Nutrition Recommendations (by Denmark, Finland, Iceland, Norway and Sweden); IOM, Institute of Medicine, Dietary Reference Intakes; WHO, Vitamin and Mineral Requirements in Human Nutrition $\left.{ }^{(42)}\right)$. Definition of periconceptional period adapted from Steegers-Theunissen et al. ${ }^{(44)}$

From the analysed countries, five had mandatory fortification (Australia, Brazil, Canada, South Africa and USA). All of these also advised folic acid supplementation.

Given the diversity of the recommendations for folate from international entities (from D-A-CH, NNR, IOM and $\mathrm{WHO}$ ), we opted to build a diagram overlapping different recommendations with gestational age, periconceptional period and neurulation period, as shown in Fig. 2.

\section{Discussion}

The association between adequate maternal folate levels during the periconceptional period and the reduction in congenital anomalies, especially NTD, is well established. However, achieving an adequate folate status in the neurulation period is a challenge worldwide, according to prior studies ${ }^{(2,6,44)}$. To fill this gap, the WHO and many national health organizations have been developing recommendations related to folic acid supplementation and a folate-rich diet. Some countries have also implemented mandatory folic acid fortification.

In public health it is indispensable to communicate widespread clear and unique messages among health professionals and the general public, once the general public is becoming more interested in a topic, to judge the information provided by health professionals.

The question of folate adequacy seeking NTD prevention is very interesting, because the critical period for that adequacy is the first six gestational weeks ${ }^{(2)}$ when the majority of women do not know they are pregnant, even in planned pregnancies (exceptions would be medically assisted pregnancies). Some authors advocate that, ideally, a correct diet would supply adequate intakes, but this is not the reality for all ${ }^{(17)}$. Supplementation could be a solution for this deficiency, but it is not always effective because women are often unaware of their pregnancies during the target period ${ }^{(15,16)}$. Food fortification with folic acid appears a better solution, providing adequate intakes. So, recommendations should have a clear message regarding at least two of the three possibilities for an adequate folate intake: diet, fortification and supplements. Mandatory fortification is restricted to countries that opt for this measure. Others may have voluntary fortification and recent EU legislation was created in order to regulate this kind of fortification ${ }^{(15)}$.

Nowadays, the World Wide Web is available for the majority of the population in many countries worldwide. This is an excellent vehicle for giving messages to health professionals and the rest of the population. For this reason, this source of information was inspected. Initially, it 
was intended to obtain information for forty-six countries, but for ten of them it was impossible to reach any information on official websites. For the other thirty-six countries diverse information was obtained. Notwithstanding that differences should exist among countries regarding different dietary patterns and different disease prevalences, probably there is not a clear rational justification for the disparities observed between countries.

Folate intake recommendations differ between international entities: D-A-CH, NNR, Scientific Committee on Food, $\operatorname{IOM}^{(2,16,38,45,46)}$ and $\mathrm{WHO}^{(28,42)}$. A huge amount of work should be done regarding dietary advice. Public health efforts should incorporate practical advice on storage and cooking to increase folate intake, helping to optimize folate status ${ }^{(47)}$, as well as recommendations on dietary pattern ${ }^{(48)}$. A prudent dietary pattern, even in the era of fortification, may decrease the risk of NTD and some heart defects in non-users of folic acid ${ }^{(48)}$. In addition to folate, other micronutrients may decrease the risk of NTD occurrence ${ }^{(49)}$ and once again promoting a healthy diet has several benefits. Furthermore, the practice of a Western diet by mothers increases the risk of offspring with a cleft lip or cleft palate approximately twofold ${ }^{(50)}$. A high preconceptional intake of nutrients predominantly present in fruits and vegetables reduces the risk of offspring affected by orofacial cleft ${ }^{(51)}$. Fast food may increase the risk of NTD ${ }^{(52)}$.

With the present study we drew a roadmap of the recommendations about folate and folic acid intake before and during pregnancy in several countries worldwide (developed countries and emerging economies) and we also included WHO recommendations because it is plausible that many other countries consider them. The recommendations differ between countries, although the majority (66.7\%) recommend folic acid supplements of $400 \mu \mathrm{g} / \mathrm{d}$, in the periconceptional period, combined with a folate-rich diet. A small number of countries emphasize the importance of a healthy diet naturally rich in folate with no need for folic acid supplementation. According to some authors ${ }^{(48)}$, this advice should be the main in all recommendations for NTD prevention ${ }^{(47)}$, namely because a healthy diet also supplies other micronutrients that may decrease the risk of NTD occurrence ${ }^{(49)}$. At the other end of the spectrum, some countries advise supplementation and have mandatory folic acid fortification.

It seems to be consensual that women at high risk of NTD benefit from higher dosages $(4-5 \mathrm{mg} / \mathrm{d}$ ) of folic acid supplementation $^{(4,26,53,54)}$. However, not all cases of NTD are preventable by increasing the folic acid intake ${ }^{(55)}$. Several other lifestyle and environmental factors as well as genetic variations may have an influence, possibly by affecting onecarbon metabolism and thus epigenetic events ${ }^{(27)}$. Known risk factors for NTD are genetic (about $60 \%{ }^{(2)}$ ), chronic alcohol intake ${ }^{(54)}$, smoking ${ }^{(53)}$, use of certain drugs (e.g. carbamazepine, phenobarbital, methotrexate) ${ }^{(53,54)}$, some pathologies (e.g. epilepsy ${ }^{(54)}$, malabsorption disorders ${ }^{(53,54)}$, obesity $^{(26,53,54)}$, pre-gestational diabetes ${ }^{(26,53,54)}$ ) and personal or family history of NTD ${ }^{(54)}$.

The current study found that the designations mentioned as the adequate period for supplementation differ between countries. It can be considered that the more adequate are the ones that include the general designation 'before conception' and that refer to 'planning plus chance of becoming pregnant'. The designation 'reproductive age' is completely broad and if supplementation is suggested these women could maintain supplementation for large periods of time, unnecessarily.

Apart from recommendations about supplementation, some countries have introduced fortification and others not. Surprisingly, one of the countries with mandatory fortification (Brazil) recommends supplementation with high doses of folic acid $(5 \mathrm{mg} / \mathrm{d}$ ) for all women and not only for those at high risk of NTD. But no evidence sustains the recommendation of such doses for all pregnant women ${ }^{(15,45)}$. Moreover, nowadays the scientific community is concerned about potential adverse effects of folic acid fortification and supplementation $^{(2,15,28-32)}$ and adverse pregnancy outcomes, early or later in life, both in the mother and child, such as increased birth weight ${ }^{(11-14)}$, insulin resistance in children $^{(34)}$ and asthma in children ${ }^{(35,36)}$.

Although carcinogenicity induced by high doses of folic acid is not completely established, this issue should continue to be studied, since it constitutes a legitimate public health concern and needs careful monitoring ${ }^{(56)}$. It is known that through exposure to mandatory food fortification and vitamin supplement use, a large number of people have an unprecedented high folic acid intake ${ }^{(57)}$ and that the capacity of the body to convert folic acid to 5-methyltetrahydrofolate is limited ${ }^{(58)}$. An inverse association was also found between the presence of unmetabolized folic acid in plasma and natural killer cell cytotoxicity, but further studies on immune function and health are needed ${ }^{(57)}$. Given the possibility that excessive folic acid exposure may relate to cancer risk, monitoring the long-term effect should be warranted ${ }^{(56,59)}$ especially considering that the vast majority of the population is not at risk of NTD ${ }^{(59)}$.

In some countries, an effort to personalize intervention was observed. Some delegated to the physician or the health provider the decision for supplementation and/or dosage. In Singapore the importance of folate status, to be achieved by diet, was mentioned.

It is not easy to know the real intake of folic acid as supplements in different countries, because many scientific studies limit this kind of information, providing only the proportion of supplemented women without reference to the dose $\mathrm{e}^{(17,60)}$. In order to measure accurately the real impact of such recommendations, systematic health registries are imperative. For instance, regarding congenital anomalies, it would be necessary to compile information regarding miscarriages, medical abortions, stillbirths and neonates with congenital information, 
information not always easy to aggregate. This is a critical issue in the comparison among countries with different levels of accuracy in their registries.

\section{Strengths and weaknesses}

As advantages of the present study we can point out its novelty, considering that all information was searched from official national health websites, a source of information that is widely used and accessible to health professionals and the general public. The previous studies found in the literature included fewer countries and did not analyse data available on the Internet ${ }^{(16,38)}$. Most data were officially validated, by email, ensuring a better accuracy. The present study allowed clustering of recommendations to check similarities and disparities within and between countries, and missing information. Countries that do not disseminate clear messages were also identified.

The study is limited by the lack of information about excluded countries, other countries worldwide and by having some countries without official validation, within which we cannot assure that other recommendations are emanated. The methodology underlying each recommendation was not analysed, nor was compliance or the impact of the recommendations in each country.

\section{Public bealth implications}

The role of folate and folic acid during pregnancy being unquestionable, the present study provides a huge amount of structured information about worldwide folate and folic acid recommendations in the periconceptional period and can form a basis for future discussions on these issues. Many questions arise at the end of the study, as follows. What are the reasons behind the different recommendations? Is there any association between recommendations and the epidemiology of NTD in the country? How can we optimize the recommendations, taking into account different sources (healthy diet, fortified foods and supplements)? How can we deal with unplanned pregnancies, other than to recommend supplementation during the entire childbearing age? Are fortified foods really a good solution when the entire population is considered (potential adverse effects)? How to reduce adverse effects in the mother, child and overall population? Is supplementation needed when women have adequate folate status before pregnancy (and considering adverse effects)? Will the future hold a place for personalized recommendations, namely based on blood analyses of folate status (serum and erythrocyte)?

\section{Conclusions}

We conclude that the recommendation more frequently used worldwide, from analysed countries and the WHO, about folic acid supplementation in the periconceptional period is $400 \mu \mathrm{g} / \mathrm{d}$. The recommendation for folate intake is in the range of $300-400 \mu \mathrm{g} / \mathrm{d}$ for women of childbearing age and $500-600 \mu \mathrm{g} / \mathrm{d}$ for pregnant women.

In some countries there are clear indications for the use of higher dosages among women with higher risk of congenital anomalies. The recommendation of a healthy diet, naturally rich in folate, is unanimous. However, big disparities were seen for the recommendations between some countries: some recommend supplementation and a healthy diet plus mandatory fortification; in contrast, some recommend only a healthy diet.

Accurate and ideally evidence-based recommendations are needed regarding folate and folic acid intake during the periconceptional period.

\section{Acknowledgements}

Acknowledgements: The authors are grateful to the Ministries of Health of the following twenty-seven countries that validated data available in the websites: Australia, Austria, Belgium, Bulgaria, Canada, Denmark, Estonia, Finland, Germany, Hong Kong, Hungary, Iceland, Ireland, Italy, Liechtenstein, Luxembourg, Malta, Netherlands, Norway, Poland, Portugal, Slovenia, Spain, Sweden, Switzerland, UK and USA. The authors are grateful to Yu-shuo Kuo who helped with research on Asian websites; and to Jessica Sheppard who helped with English revision. Financial support: This research received no specific grant from any funding agency in the public, commercial or not-for-profit sectors. The views expressed in this article are the authors' own and do not reflect an official position of any institution. Conflict of interest: None. Authorship: E.P. and S.G. were responsible for designing the study. S.G. was responsible for data collection, the contacts with national entities and the statistical analyses. S.G. wrote the manuscript jointly with E.P. and C.L. All three authors contributed to the interpretation of the findings and approved the contents of this manuscript.

\section{References}

1. Rosano A, Botto LD, Botting B et al. (2000) Infant mortality and congenital anomalies from 1950 to 1994: an international perspective. J Epidemiol Community Health 54, 660-666.

2. Institute of Medicine (1998) Dietary Reference Intakes for Thiamin, Riboflavin, Niacin, Vitamin $B_{6}$, Folate, Vitamin $B_{12}$, Pantothenic Acid, Biotin, and Choline. Washington, DC: National Academies Press.

3. Herrmann W \& Obeid R (2011) The mandatory fortification of staple foods with folic acid: a current controversy in Germany. Dtsch Arztebl Int 108, 249-254.

4. MRC Vitamin Study Research Group (1991) Prevention of neural tube defects: results of the Medical Research Council Vitamin Study. Lancet 338, 131-137.

5. Czeizel AE \& Dudas I (1992) Prevention of the first occurrence of neural-tube defects by periconceptional vitamin supplementation. $N$ Engl J Med 327, 1832-1835. 
6. Institute of Medicine (2006) Dietary Reference Intakes: The Essential Guide to Nutrient Requirements [JJ Otten, JP Hellwig and LD Meyers, editors]. Washington, DC: The National Academies Press.

7. Wilcox AJ, Lie RT, Solvoll K et al. (2007) Folic acid supplements and risk of facial clefts: national population based case-control study. BMJ 334, 464.

8. Kelly D, O'Dowd T \& Reulbach U (2012) Use of folic acid supplements and risk of cleft lip and palate in infants: a population-based cohort study. $\mathrm{BrJ}$ Gen Pract 62, e466-e472.

9. De-Regil LM, Fernandez-Gaxiola AC, Dowswell T et al. (2010) Effects and safety of periconceptional folate supplementation for preventing birth defects. Cochrane Database Syst Rev issue 10, CD007950.

10. Rozendaal AM, van Essen AJ, Te Meerman GJ et al. (2013) Periconceptional folic acid associated with an increased risk of oral clefts relative to non-folate related malformations in the Northern Netherlands: a population based case-control study. Eur J Epidemiol 28, 875-887.

11. Charles DH, Ness AR, Campbell D et al. (2005) Folic acid supplements in pregnancy and birth outcome: re-analysis of a large randomised controlled trial and update of Cochrane review. Paediatr Perinat Epidemiol 19, 112-124.

12. de Benoist B (2008) Conclusions of a WHO Technical Consultation on folate and vitamin $\mathrm{B}_{12}$ deficiencies. Food Nutr Bull 29, 2 Suppl, S238-S244.

13. Fekete K, Berti C, Trovato M et al. (2012) Effect of folate intake on health outcomes in pregnancy: a systematic review and meta-analysis on birth weight, placental weight and length of gestation. Nutr J 11, 75.

14. Lassi ZS, Salam RA, Haider BA et al. (2013) Folic acid supplementation during pregnancy for maternal health and pregnancy outcomes. Cochrane Database Syst Rev $\mathbf{3}$, CD006896.

15. European Food Safety Authority (2009) Folic acid: an update on scientific developments. http://www.efsa. europa.eu/fr/supporting/doc/2e.pdf (accessed March 2015).

16. Botto LD, Lisi A, Robert-Gnansia E et al. (2005) International retrospective cohort study of neural tube defects in relation to folic acid recommendations: are the recommendations working? BMJ 330, 571.

17. Pinto E, Barros H \& dos Santos Silva I (2009) Dietary intake and nutritional adequacy prior to conception and during pregnancy: a follow-up study in the north of Portugal. Public Health Nutr 12, 922-931.

18. World Health Organization (2012) WHO Guidelines Approved by the Guidelines Review Committee. Guideline: Daily Iron and Folic Acid Supplementation in Pregnant Women. Geneva: WHO.

19. World Health Organization (2006) Prevention of Neural Tube Defects. Standards for Maternal and Neonatal Care. Geneva: WHO, Department of Making Pregnancy Safer.

20. Singh S, Sedgh G \& Hussain R (2010) Unintended pregnancy: worldwide levels, trends, and outcomes. Stud Fam Plann 41, 241-250.

21. Butterworth CE Jr \& Tamura T (1989) Folic acid safety and toxicity: a brief review. Am J Clin Nutr 50, 353-358.

22. United Nations (2012) Composition of macro geographical (continental) regions, geographical sub-regions, and selected economic and other groupings. http://unstats.un. org/unsd/methods/m49/m49regin.htm (accessed October 2013).

23. EUROCAT (2013) World map of countries having mandatory fortification of food with folic acid. http:// www.eurocat-network.eu/content/EUROCAT-FolicAcid-Map.pdf (accessed September 2013).
24. Williams LJ, Rasmussen SA, Flores A et al. (2005) Decline in the prevalence of spina bifida and anencephaly by race/ethnicity: 1995-2002. Pediatrics 116, 580-586.

25. De Wals P, Tairou F, Van Allen MI et al. (2007) Reduction in neural-tube defects after folic acid fortification in Canada. $N$ Engl J Med 357, 135-142.

26. Kondo A, Kamihira O \& Ozawa H (2009) Neural tube defects: prevalence, etiology and prevention. Int J Urol 16, $49-57$.

27. Osterhues A, Ali NS \& Michels KB (2013) The role of folic acid fortification in neural tube defects: a review. Crit Rev Food Sci Nutr 53, 1180-1190.

28. Food and Agriculture Organization of the United Nations \& World Health Organization (2001) Human Vitamin and Mineral Requirements. Report of a Joint FAO/WHO Expert Consultation, Bangkok, Thailand. Rome: FAO; available at http://www.fao.org/3/a-y2809e.pdf.

29. Cole BF, Baron JA, Sandler RS et al. (2007) Folic acid for the prevention of colorectal adenomas: a randomized clinical trial. JAMA 297, 2351-2359.

30. Ebbing M, Bonaa KH, Nygard O et al. (2009) Cancer incidence and mortality after treatment with folic acid and vitamin $\mathrm{B}_{12}$. JAMA 302, 2119-2126.

31. Kennedy DA, Stern SJ, Moretti M et al. (2011) Folate intake and the risk of colorectal cancer: a systematic review and meta-analysis. Cancer Epidemiol 35, 2-10.

32. Vollset SE, Clarke R, Lewington S et al. (2013) Effects of folic acid supplementation on overall and site-specific cancer incidence during the randomised trials: metaanalyses of data on 50,000 individuals. Lancet 381, 1029-1036.

33. National Center for Biotechnology Information (2013) MeSH - Pregnancy Outcome. http://www.ncbi.nlm.nih. gov/mesh/?term=pregnancy+outcomes (accessed October 2013).

34. Yajnik CS, Deshpande SS, Jackson AA et al. (2008) Vitamin $\mathrm{B}_{12}$ and folate concentrations during pregnancy and insulin resistance in the offspring: the Pune Maternal Nutrition Study. Diabetologia 51, 29-38.

35. Burdge GC \& Lillycrop KA (2012) Folic acid supplementation in pregnancy: are there devils in the detail? BrJ Nutr 108, 1924-1930.

36. Whitrow MJ, Moore VM, Rumbold AR et al. (2009) Effect of supplemental folic acid in pregnancy on childhood asthma: a prospective birth cohort study. Am J Epidemiol 170, 1486-1493.

37. European Commission (2013) Trustworthy websites on 'Population groups'. http://ec.europa.eu/health/ population_groups/portal/index_en.htm\#tab_my_country (accessed October 2013).

38. European Food Safety Authority (2009) ESCO report prepared by the EFSA Scientific Cooperation Working Group on Analysis of Risks and Benefits of Fortification of Food with Folic Acid. http://www.efsa.europa.eu/en/scdocs/ doc/3e.pdf (accessed October 2013).

39. Theodosiou L \& Green J (2003) Emerging challenges in using health information from the internet. Adv Psychiatr Treat 9, 387-396.

40. Mo P (2012) The use of internet for health education. J Biosafety Health Educ 1, e102.

41. Houston TK \& Allison JJ (2002) Users of Internet health information: differences by health status. $J$ Med Internet Res 4, E7.

42. World Health Organization \& Food and Agriculture Organization of the United Nations (2004) Vitamin and Mineral Requirements in Human Nutrition, 2nd ed. Geneva: WHO; available at http://whqlibdoc.who.int/ publications/2004/9241546123.pdf

43. United Nations University/World Health Organization/ Food and Agriculture Organization of the United Nations 
(2004) Human Energy Requirements: Report of a Joint FAO/WHO/UNU Expert Consultation, Rome, 17-24 October 2001. Rome: FAO; available at http://www.fao.org/ docrep/007/y5686e/y5686e00.htm

44. Steegers-Theunissen RP, Twigt J, Pestinger V et al. (2013) The periconceptional period, reproduction and long-term health of offspring: the importance of one-carbon metabolism. Hum Reprod Update 19, 640-655.

45. Institute of Medicine (2006) Dietary reference intakes for thiamin, riboflavin, niacin, vitamin $\mathrm{B}_{6}$, folate, vitamin $\mathrm{B}_{12}$, pantothenic acid, biotin, and choline. In Dietary Reference Intakes Research Synthesis Workshop Summary, pp. 35-38 [CW Suitor and LD Meyers, rapporteurs]. Washington, DC: The National Academies Press.

46. Commission of the European Communities (1993) Reports of the Scientific Committee on Food (Thirty-first Series) Nutrition and Energy Intakes for the European Community. Luxembourg: Office for Official Publications of the European Communities.

47. McKillop DJ, Pentieva K, Daly D et al. (2002) The effect of different cooking methods on folate retention in various foods that are amongst the major contributors to folate intake in the UK diet. BrJ Nutr 88, 681-688.

48. Sotres-Alvarez D, Siega-Riz AM, Herring AH et al. (2013) Maternal dietary patterns are associated with risk of neural tube and congenital heart defects. Am J Epidemiol 177, $1279-1288$.

49. Chandler AL, Hobbs CA, Mosley BS et al. (2012) Neural tube defects and maternal intake of micronutrients related to one-carbon metabolism or antioxidant activity. Birth Defects Res A Clin Mol Teratol 94, 864-874.

50. Vujkovic M, Ocke MC, van der Spek PJ et al. (2007) Maternal Western dietary patterns and the risk of developing a cleft lip with or without a cleft palate. Obstet Gynecol 110, 378-384.

51. Krapels IP, van Rooij IA, Ocke MC et al. (2004) Maternal nutritional status and the risk for orofacial cleft offspring in humans. J Nutr 134, 3106-3113.

52. Sumiyoshi Y (2007) How do we react on folic acid deficiency? Brain Spinal Cord 14, 1-3.

53. Kennedy D \& Koren G (2012) Identifying women who might benefit from higher doses of folic acid in pregnancy. Can Fam Physician 58, 394-397.

54. Talaulikar VS \& Arulkumaran S (2011) Folic acid in obstetric practice: a review. Obstet Gynecol Surv 66, 240-247.

55. Heseker HB, Mason JB, Selhub J et al. (2009) Not all cases of neural-tube defect can be prevented by increasing the intake of folic acid. Br J Nutr 102, 173-180.

56. Kim YI (2004) Will mandatory folic acid fortification prevent or promote cancer? Am J Clin Nutr 80, 1123-1128.

57. Troen AM, Mitchell B, Sorensen B et al. (2006) Unmetabolized folic acid in plasma is associated with reduced natural killer cell cytotoxicity among postmenopausal women. J Nutr 136, 189-194.

58. Kelly P, McPartlin J, Goggins M et al. (1997) Unmetabolized folic acid in serum: acute studies in subjects consuming fortified food and supplements. Am J Clin Nutr 65, 1790-1795.

59. Bailey RL, Mills JL, Yetley EA et al. (2010) Unmetabolized serum folic acid and its relation to folic acid intake from diet and supplements in a nationally representative sample of adults aged $\geq 60 \mathrm{y}$ in the United States. Am J Clin Nutr 92, 383-389.

60. Lunet N, Rodrigues T, Correia S et al. (2008) Adequacy of prenatal care as a major determinant of folic acid, iron, and vitamin intake during pregnancy. Cad Saude Publica 24, 1151-1157.

61. National Health and Medical Research Council (2013) Australian Dietary Guidelines. http://www.nhmrc.gov. au/_files_nhmrc/publications/attachments/n55_australian_ dietary_guidelines_0.pdf (accessed December 2014).
62. National Health and Medical Research Council (2005) Nutrient Reference Values for Australia and New Zealand. http://www.nhmrc.gov.au/_files_nhmrc/publications/ attachments/n35.pdf (accessed December 2014).

63. Food Standards Australia New Zealand (2013) Folic acid/ folate and pregnancy. http://www.foodstandards.gov.au/ consumer/generalissues/pregnancy/folic/Pages/default. aspx (accessed December 2014).

64. Federal Ministry of Health, Austria - Public Health Portal (2014) Folat. https://www.gesundheit.gv.at/Portal.Node/ ghp/public/content/Folsaeure_Folat_KH.html. Ernährung in der Schwangerschaft, https://www.gesundheit.gv.at/ Portal.Node/ghp/public/content/Ernaehrung_Schwan gerschaftLN.html (accessed December 2014).

65. D-A-CH (2013) Referenzwerte für die Nährstoffzufuhr Folat. http://relaunch-live.dge.de/fileadmin/public/doc/ws/ ref/Referenzwerte-Folat.pdf, http://www.dge.de/wissenschaft/ stellungnahmen/faq/folat/ (accessed December 2014).

66. Hoppenbrouwers K, Roelants M, Guérin C et al. (2010) Preventie van spina bifida en andere neuralebuis defecten door foliumzuursuppletie tijdens de zwangerschap. http://www.kindengezin.be/img/foliumzu ursuppletie.pdf (accessed December 2014).

67. Flemish Government - Child and Family Support Centre for Policy Research - Welfare, Health and Family (2014) Foliumzuur. http://www.kindengezin.be/zwangerschapen-geboorte/zwanger/voeding-en-beweging/foliumzuur/ (accessed December 2014).

68. Ministério da Saúde (2012) Cadernos de Atenção Básica, $n^{\circ} 32$ - Atenção ao pré-natal de baixo risco. Normas e Manuais Técnicos. http://189.28.128.100/dab/docs/ publicacoes/geral/caderno_atencao_pre_natal_baixo_risco. pdf (accessed December 2014).

69. Ministério da Saúde (2006) Caderno no 5-Manual Técnico Pré-natal e puerpério - Atenção qualificada e humanizada. Série Direitos Sexuais e Direitos Reprodutivos. http:// bvsms.saude.gov.br/bvs/publicacoes/manual_pre_natal_puer perio_3ed.pdf (accessed December 2014).

70. Official Bulgarian Patient Organization 'Conception' (2014) Folacid: Какво е фолиева киселина? http://www. zachatie.org/index.php?option=com_content\&view=article \&id=498:folacid- - - $\&$ \&atid=164:- - sp-429\&Itemid=135\&high light=WyJcdTA0NDRcdTA0M2VcdTA0M2JcdTA0MzhcdT A0MzVcdTA0MzJcdTA0MzAiLCJcdTA0M2FcdTA0MzhcdT A0NDFcdTA0MzVcdTA0M2JcdTA0MzhcdTA0M2RcdTA0M zAiLCJcdTA0NDRcdTA0M2VcdTA0M2JcdTA0MzhcdTA0M zVcdTA0MzJcdTA0MzAgXHUwNDNhXHUwNDM4XHUw NDQxXHUwNDM1XHUwNDNiXHUwNDM4XHUwNDNk XHUwNDMwIl0 $=($ accessed December 2014 $)$.

71. Health Canada (2009) Prenatal Nutrition Guidelines for Health Professionals - Folate Contributes to a Healthy Pregnancy. http://www.hc-sc.gc.ca/fn-an/alt_formats/ hpfb-dgpsa/pdf/pubs/folate-fra.pdf (accessed December 2014).

72. Health Canada (2010) High Dose Folic Acid Supplementation - Questions and Answers for Health Professionals. http://www.hc-sc.gc.ca/fn-an/nutrition/prenatal/ fol-qa-qr-fra.php (accessed December 2014).

73. Agence de la santé publique du Canada (2002) Pourquoi toutes les femmes qui pourraient devenir enceintes devraient prendre de l'acide folique. http://www.phacaspc.gc.ca/fa-af/pdf/brochure_f.pdf (accessed December 2014).

74. Health Canada (2010) Dietary Reference Intakes - Definitions. http://www.hc-sc.gc.ca/fn-an/alt_formats/hpfb-dgpsa/ pdf/nutrition/dri_tables-eng.pdf (accessed December 2014).

75. 健康e站 (E-health - Shanghai Jing'an District Health Promotion Board - Ministry of Health) (2014) http://www. ejiankang.org/articles/12, http://www.ejiankang.org/ articles/225 (accessed December 2014). 
76. 中国营养学会 (Chinese Nutrition Society) (2007) http:// www.cnsoc.org/cn/nutrition.asp (accessed December 2014).

77. Danish Health and Medicines Authority (2014) Graviditet: Spis folsyre, jern, D-vitamin og eventuelt kalk som kosttilskud. http://sundhedsstyrelsen.dk/da/sundhed/ graviditet/anbefalinger-til-gravide/folsyre,-jern,-d-vitamin-ogeventuelt-kalk (accessed December 2014).

78. Sundhedsstyrelsen (National Board of Health) (2010) Healthy habits before, during and after pregnancy. http://sun dhedsstyrelsen.dk/publ/Publ2010/CFF/English/Sun deVaner_en.pdf (accessed December 2014).

79. Nordic Council of Ministers (2014) Nordic Nutrition Recommendations 2012: Integrating nutrition and physical activity. http://dx.doi.org/10.6027/Nord2014-002 (accessed December 2014).

80. Tervise Arengu Instituut, Eesti Toitumisteaduse Selts (2006) Eesti toitumis - ja toidusoovitused. https://intra.tai. ee/images/prints/documents/130311768374_Eesti_toitumis_ ja_toidusoovitused_est.pdf (accessed December 2014).

81. Tervise Arengu Instituut, Eesti Ämmaemandate Ühing (2008) Rasedate ja imetavate toitumis - ja toidusoovitused. http://www.kliinikum.ee/attachments/article/522/rasedate_ ja_imetavate_emade_toitumis_ja_toidusoovitused.pdf (accessed December 2014).

82. Health Information Network (2011) Фолиевая кислота что это и для чего?. http://www.terviseinfo.ee/et/compo nent $/$ search/?searchword=foolhape $\& x=-1383 \& y=-52 \&$ Itemid $=131$ (accessed December 2014).

83. Ravijuhend (2014) Foolhape - mis ja milleks? Foolhappe osatähtsus terve beebi sündimisel. http://ravijuhend.ee/ kasutajale/pj/foolhape-mis-ja-milleks-foolhappe-osatahtsusterve-beebi-syndimisel- (accessed December 2014).

84. Hasunen K, Kalavainen M, Keinonen H et al. (2004) Lapsi, perhe ja ruoka. http://www.stm.fi/c/document_library/ get_file?folderId=28707\&name=DLFE-3555.pdf\&title=Lapsi_ perhe_ja_ruoka_fi.pdf (accessed December 2014).

85. Programme National Nutrition Santé (2007) Le guide nutrition pendant et après la grossesse. http://www. inpes.sante.fr/cfesbases/catalogue/pdf/1059.pdf (accessed December 2014).

86. Institute national de prévention et d'éducation pour la santé (2014) Vous avez un projet de bébé? Pensez dès maintenant à la vitamine $B_{9}$. http://www.inpes.sante.fr/ CFESBases/catalogue/pdf/1429.pdf (accessed December 2014).

87. Institute national de prévention et d'éducation pour la santé (2011) Folates et désir de grossesse: informer et prescrire au bon moment. Les essentiels de l'INPES. http:// www.inpes.sante.fr/professionnels-sante/pdf/folates-gros sesses.pdf (accessed December 2014).

88. Manger Bouger - Programme National Nutrition Santé (2014) Les folates. http://www.mangerbouger.fr/pour-qui-242/ future-maman/manger-de-facon-adaptee/avant-la-grossesse/ les-folates.html (accessed December 2014).

89. Familienplanung - Bundeszentrale für gesundheitliche Aufklärung (2014) Lexikon - Folsäure-Prophylaxe. http:// www.familienplanung.de/lexikon/folsaeure-prophylaxe/ (accessed December 2014).

90. 衛生署 (Department of Health) (2013) Healthy eating during pregnancy and breastfeeding. http://www.fhs.gov. hk/english/health_info/woman/20036.pdf (accessed December 2014).

91. The Hong Kong College of Obstetricians and Gynaecologists (2008) HKCOG Guidelines - Guidelines on Antenatal Care (Part I). http://hkcog.obg.cuhk.edu.hk/ docs/college_guidelines/Guidelines_on_Antenatal_Care_\%28 Part_1\%29_2008.pdf (accessed December 2014).

92. Agoston H, Bics E, Domonkos A et al. (2005) Táplálkozási ajánlások várandós és szoptató anyáknak. http://www. oeti.hu/download/taplalkozasi_ajanlasok_varandos.pdf (accessed December 2014).

93. Directorate of Health (2007) Fólat. http://www.land laeknir.is/servlet/file/store93/item2792/version7/3252.pdf (accessed December 2014).

94. Directorate of Health (2004) Forvarnir með fólasíni. http:// www.landlaeknir.is/servlet/file/store93/item2350/version4/ 2046.pdf (accessed December 2014).

95. Health Service Executive (2006) Training Programme for Public Health Nurses and Doctors in Child Health Screening, Surveillance and Health Promotion. Unit 7: Food \& Nutrition. http://www.hse.ie/eng/services/ Publications/Children/Unit_7_Food_and_Nutrition.pdf (accessed December 2014).

96. Ministero della Salute (2013) http://www.salute.gov.it/ servizio/galleria.jsp?lang=italiano\&id $=543 \& \mathrm{dad}=$ s\&men $=$ campagne07\&label=genit (accessed December 2014).

97. Ministero della Salute (2009) 7 Azioni per la vita del tuo bambino. Genitori Più - Prendiamoci più cura della loro vita-Materiale informativo per gli operatori. http://www. salute.gov.it/imgs/C_17_opuscoliPoster_126_allegato. pdf (accessed December 2014).

98. Ministry of Health Labour and Welfare (2009) 葉酸 (Folate). http://www.mhlw.go.jp/shingi/2009/05/dl/ s0529-4u.pdf (accessed December 2014).

99. Medicine - Latvijas veselibas portals (2013) Folijskābe grūtniecības laikā. http://www.medicine.lv/raksti/ folijskabe-grutniecibas-laika (accessed December 2014).

100. Ministère de la Santé (2009) L'Alimentation saine pendant la grossesse. http://www.sante.public.lu/publications/ rester-bonne-sante/alimentation/alimentation-saine-grossesse/ alimentation-saine-grossesse-2009-fr.pdf (accessed December 2014).

101. Ministry for Health - Malta (2013) Registries. Birth defects. Malta Congenital Anomalies Registry. https://ehealth.gov. $\mathrm{mt} /$ HealthPortal/chief_medical_officer/healthinfor_research/ registries/birth_defects.aspx (accessed December 2014).

102. National Institute for Public Health and Environment Ministry of Health, Welfare and Sport (2014) Toolkits voor publiekscommunicatie. http://toolkits.loketgezondleven. nl/toolkits/?page_id=1754\#link_5487 (accessed December 2014).

103. Voedingscentrum (2014) Zwanger. http://www.voed ingscentrum.nl/nl/mijn-kind-en-ik/zwanger.aspx (accessed December 2014).

104. Folkehelseinstituttet (2014) Folat - Folattilskudd og svangerskap faktaark. http://www.fhi.no/eway/default.aspx?pid=239 \&trg=List_6212\&Main_6157=6263:0:25,6665\&MainContent_ $6263=6464: 0: 25,6667 \&$ List_6212 $=6218: 0: 25,6685: 1: 0: 0:: 0: 0$ (accessed December 2014).

105. Ministerstwo Zdrowia (2011) Żywienie w ciąży - porady żywieniowe dla przyszłych mam. http://www2.mz.gov.pl/ wwwfiles/ma_struktura/docs/polzdrow_broszciaza_20120 523zal12.pdf (accessed December 2014).

106. Direcção-Geral da Saúde (2006) Circular Normativa no 2/ DSMIA de 16/01/2006. http://www.dgs.pt/directrizesda-dgs/normas-e-circulares-normativas/circular-normativa-n2dsmia-de-16012006.aspx (accessed December 2014).

107. Societatea de Nutritie din Romania (2006) Ghid pentru alimentatia sanatoasa. http://www.ms.ro/documente/ Ghid1_8318_6022.pdf (accessed December 2014).

108. здоровая россия (Healthy Russia) (2013) Фолиевая кислота. http://www.takzdorovo.ru/pitanie/zdorovoepitanie/folievaya-kislota/ (accessed December 2014).

109. Health Promotion Board (2012) Preganacy and diet, http:// www.hpb.gov.sg/HOPPortal/health-article/3826. Conception to Birth: Eating For A Healthy Baby, http://www.hpb. gov.sg/HOPPortal/health-article/2740. Recommended Dietary Allowances, http://www.hpb.gov.sg/HOPPortal/ article?id=2652 (accessed December 2014). 
110. Institute za Varovanje Zdravja - Republike Slovenije (2013) Referencne vrednosti za vnos vitaminov in mineralov. http://www.ivz.si/prehrana?pi=5\&_5_Filename=attName. png\&_5_MediaId=6551\&_5_AutoResize $=$ false $\& \mathrm{pl}=8-5.3$ (accessed December 2014).

111. Ministrstvo za Zdravje - Republike Slovenije (2014) http:// www.mz.gov.si/si/delovna_podrocja/javno_zdravje/sektor_ za_krepitev_zdravja_in_zdrav_zivljenjski_slog/prehrana/ publikacije_in_druga_gradiva/ (accessed December 2014).

112. Department of Health (2003) Human genetics policy guidelines for the management and prevention of genetic disorders, birth defects and disabilities. http://www.gov. za/sites/www.gov.za/files/humangenetics_0.pdf (accessed December 2014).

113. National Nutrition Week (2012) Nutritional tips before and during pregnancy. http://www.nutritionweek.co.za/preg nancy/31food.html (accessed December 2014).

114. Ministerio de Sanidad Política Social e Igualdad (2011) Estrategia Nacional de Salud Sexual y Reproductiva. http:// www.msssi.gob.es/organizacion/sns/planCalidadSNS/pdf/ equidad/ENSSR.pdf (accessed December 2014).

115. Ministerio de Sanidad Política Social e Igualdad (2006) Guía para la Prevención de Defectos Congénitos. http://www. msssi.gob.es/profesionales/prestacionesSanitarias/publi caciones/docs/GuiaPrevencionDDCC.pdf (accessed December 2014).

116. Swedish National Food Administration (2008) Advice about food for you who are pregnant. http://www.slv.se/ upload/dokument/mat/kostrad/gravida_ammande/advice_ about_food_pregnant.pdf (accessed December 2014).

117. Livsmedelsverket (2014) Råd om folsyra. http://www.slv. se/sv/grupp1/Mat-och-naring/Kostrad/Rad-om-folsyra/ (accessed December 2014)

118. Schweizerische Gesellschaft für Ernährung, Société Suisse de Nutrition, Società Svizzera di Nutrizione (2012) L'alimentation de la femme enceinte. http://www. sge-ssn.ch/media/medialibrary/2012/06/feuille_d_info_alimen tation_de_la_femme_enceinte_2011.pdf (accessed December 2014).
119. Office Fédéral de la Santé Publique (2014) http://www.bag. $\mathrm{admin} . \mathrm{ch} / \mathrm{suchen} /$ index.html?lang=fr\&keywords=grossesse + folate\&search_mode $=$ AND\&from_day $=\&$ from_month $=\&$ from_year=\&to_day $=\&$ to_month $=\&$ to_year $=\&$ column $=\&$ dok umenttyp $=\&$ site_mode $=$ extern\&nsb_mode $=y e s \& S u b m i t=r e c$ hercher ${ }^{\#}$ Volltextsuche (accessed December 2014).

120. Health Promotion Administration - Ministry of Health and Welfare (2009) 孕婦健康手冊 (Maternal Health Handbook). http://www.hpa.gov.tw/bhpnet/Portal/file/ ThemeULFile/200904290238200193/\%E5\%AD\%95\%E5\%A9\% A6\%E5\%81\%A5\%E5\%BA\%B7\%E6\%89\%8B\%E5\%86\%8A_\% E8\%8B\%B1\%E6\%96\%87\%E7\%89\%881.pdf (accessed December 2014)

121. 食品藥品監督管理局 (Food and Drug Administration) (2010) https://consumer.fda.gov.tw/Pages/List.aspx? nodeID=636 (accessed December 2014).

122. 食品藥品監督管理局 (Food and Drug Administration) (2009) https://consumer.fda.gov.tw/Files/eweekly/\%E7\%AC $\% \mathrm{AC} 213 \% \mathrm{E} 6 \%$ C\%9F\%E6\%A0\%B8\%E5\%AE\%9A\%E7\%A8\%BF .doc (accessed December 2014).

123. NHS (2014) Vitamins and nutrition in pregnancy. http:// www.nhs.uk/conditions/pregnancy-and-baby/pages/vitam ins-minerals-supplements-pregnant.aspx ${ }^{\#}$ close (accessed December 2014).

124. Institute of Medicine (1998) Dietary Reference Intakes. http://www.iom.edu/Activities/Nutrition/SummaryDRIs/ / media/Files/Activity\%20Files/Nutrition/DRIs/New\%20 Material/2_\%20RDA\%20and\%20AI\%20Values_Vitamin \%20and\%20Elements.pdf (accessed December 2014).

125. Centers for Disease Control and Prevention (2010) Folic Acid: Questions and Answers. http://www.cdc.gov/ ncbddd/folicacid/documents/qanda_english.pdf (accessed December 2014).

126. Centers for Disease Control and Prevention (2014) Folic Acid Reccomendations. http://www.cdc.gov/ncbddd/folic acid/recommendations.html (accessed December 2014).

127. Women's Health (2014) Folic acid fact sheet. http://www. womenshealth.gov/publications/our-publications/fact-sheet/ folic-acid.html (accessed December 2014). 